\title{
In-Line Sputtered Gallium and Aluminum Codoped Zinc Oxide Films for Organic Solar Cells
}

\author{
Shang-Chou Chang \\ Department of Electrical Engineering, Kun Shan University, Tainan 71070, Taiwan \\ Correspondence should be addressed to Shang-Chou Chang; jchang@mail.ksu.edu.tw
}

Received 23 June 2014; Accepted 17 July 2014; Published 5 August 2014

Academic Editor: Teen-Hang Meen

Copyright (C) 2014 Shang-Chou Chang. This is an open access article distributed under the Creative Commons Attribution License, which permits unrestricted use, distribution, and reproduction in any medium, provided the original work is properly cited.

\begin{abstract}
Gallium and aluminum codoped zinc oxide (GAZO) films were deposited at different temperatures by in-line sputtering. Aluminum is thermally unstable compared to other elements in GAZO films. The grains of GAZO films increase with deposition temperature. Coalescence between grains was observed for GAZO films deposited at $250^{\circ} \mathrm{C}$. The deposition temperature exhibits positive influence on crystallinity, and electrical and optical properties of GAZO films. The carrier concentration and mobility of GAZO films increase, while the electrical resistivity of GAZO films decreases with deposition temperature. The average optical transmittance of GAZO films rises with deposition temperature. In-line sputtering demonstrates a potential method with simplicity, mass production, and large-area deposition to produce GAZO films with good electrical and optical quality. The electrical resistivity of $4.3 \times 10^{-4} \Omega \mathrm{cm}$ and the average optical transmittance in the visible range from 400 to $800 \mathrm{~nm}$ of $92 \%$ can be obtained for GAZO films deposited at $250^{\circ} \mathrm{C}$. The hybrid organic solar cells (OSC) were fabricated on GAZO-coated glass substrates. Blended poly(3hexylthiophene) (P3HT) and [6,6]-phenyl C61 butyric acid methyl ester (PCBM) were the photoactive materials in OSC. The power conversion efficiency of OSC is $0.65 \%$ for the OSC with the $250^{\circ} \mathrm{C}$ deposited GAZO electrode.
\end{abstract}

\section{Introduction}

Transparent conductive oxides (TCO) are widely used in fabricating transparent electrodes of solar cells, touch panel displays, organic light emitting devices, and transparent thin films transistors $[1,2]$. Tin doped indium oxide (ITO) is the commonly used materials of TCO nowadays due to its excellent electrical and optical properties. However, there are demerits for ITO. Indium in ITO is expensive and indium oxide is easily reduced in hydrogen plasma [3, 4]. Impurity doped $\mathrm{ZnO}$ has been developed as alternative to ITO for several advantages: lower cost, lower synthesis temperature, higher etch ability, and higher resistance to hydrogen plasma reduction. The aluminum doped zinc oxide (AZO) and gallium doped zinc oxide (GZO) have been most widely used in impurity doped $\mathrm{ZnO}$ [5]. Good electrical and optical properties of AZO were reported. The AZO has better resistance over ITO in hydrogen plasma reduction. The hydrogen plasma is often encountered in fabricating transparent electrodes of amorphous silicon [6,7]. Gallium is less reactive and more resistant to oxidation compared to $\mathrm{Al}[8,9]$. The diffusivity of Ga is smaller than that of $\mathrm{Al}$ such that Ga causes less diffusion-related problems [10].

Ionic and covalent radii of $\mathrm{Ga}$ are 0.62 and $1.26 \AA$, respectively, close to those of $\mathrm{Zn}(0.74$ and $1.31 \AA)$, compared with those of $\mathrm{Al}(0.50$ and $1.26 \AA)$ [11]. The covalent bond length of $\mathrm{Ga}-\mathrm{O}(1.92 \AA)$ is almost the same as that of $\mathrm{Zn}-\mathrm{O}$ $(1.97 \AA)$ [8]. Less deformation of $\mathrm{ZnO}$ lattice is expected when $\mathrm{Ga}$ atoms substitute $\mathrm{Zn}$ sites in $\mathrm{ZnO}$ crystal lattice [12]. Gallium and aluminum codoped zinc oxide (GAZO) films were fabricated and expected to obtain the benefits of both AZO and GZO films. The GAZO films have been prepared by several deposition methods such as pulsed laser deposition, cosputtering, and facing targets sputtering $[2,10,13-15]$. Inline sputtering technique is widely used in mass-production system for large-sized substrates. The substrates pass linearly along one or more sputter cathodes to acquire thin film coating. This work applied in-line sputtering techniques to fabricate GAZO films with various deposition temperatures. Structural, electrical, and optical characteristics of in-line sputtered GAZO films were explored. Organic solar cells (OSC) with $\mathrm{ZnO}$ based electrode have been reported in 
recent years [16-21]. Few or no reports were found for using GAZO films as the electrode of OSC. The GAZO films found with good electrical and optical properties were used as the electrode to replace ITO in fabricating hybrid OSC. The process flow of fabricating OSC was similar to the hybrid OSC with ITO electrode used in our group $[22,23]$.

\section{Experimental Procedure}

Borosilicate glass was applied as the substrate that GAZO films were deposited on. The borosilicate glass was treated with ultrasonic cleaning using purified water and acetone in sequence to remove grease and debris. The glass was then cleaned with purified water and dried with nitrogen. One inline sputtering tool was used to deposit GAZO films. The DC power of sputtering cathode was $6 \mathrm{~kW}$. The ceramic GAZO target was with $\mathrm{Zn}: \mathrm{O}: \mathrm{Ga}: \mathrm{Al}=44: 53: 2: 1$ at\% in composition and $950 \times 125 \mathrm{~mm}^{2}$ in size. The sputtering power density was $2.53 \mathrm{~W} / \mathrm{cm}^{2}$. The process chamber was pumped down to $1 \times 10^{-3} \mathrm{~Pa}$ as base pressure. The process pressure was kept at $3 \times 10^{-1} \mathrm{~Pa}$ with feeding argon in flow rate of $300 \mathrm{sccm}$. The substrate was moved linearly along the sputtering cathode with speed of $6 \mathrm{~mm} / \mathrm{sec}$ during sputtering. The deposition temperature was varied from room temperature (RT) to $250^{\circ} \mathrm{C}$. The film thickness of deposited GAZO films was $500 \mathrm{~nm}$.

The crystalline structure, films composition, and surface morphology of GAZO films deposited at various substrate temperatures were probed with an X-ray diffract meter (model D/MAX-2500V, Rigaku), energy dispersive spectrometer (EDS), and field emission scanning electron microscope (FESEM) (model JSM-6700F, JEOL), respectively. The carrier concentration, mobility, and electrical resistivity of GAZO films were explored by a Hall measurement with van der Pauw method (model HMS-3000, Ecopia). The optical transmittance of GAZO films was measured by an UVVIS spectrophotometer (model U-2800A, Hitachi). Structural, electrical, and optical characteristics of GAZO films deposited at various temperatures were compared.

The produced GAZO films found with good electrical and optical characteristics were used as the electrode to produce hybrid OSC. The GAZO glass substrates were oxygen plasma cleaned by an inductively coupled plasma system to make the surface of GAZO films hydrophilic. A layer of poly(3,4-ethylenedioxythiophene):poly(styrenesulfonate) (PEDOT:PSS, Baytron P 4083) about $40 \mathrm{~nm}$ thick was spincoated on the GAZO substrate and baked at $120^{\circ} \mathrm{C}$ for $30 \mathrm{~min}$. The photoactive layer was made of poly(3-hexylthiophene) (P3HT) (FEM. Inc.) and [6,6]-phenyl C61 butyric acid methyl ester (PCBM) (Nano-C) dissolved in 1,2-dichlorobenzene. The $\mathrm{P} 3 \mathrm{HT}$ and $\mathrm{PCBM}$ were $10: 8 \mathrm{wt} \%$ in proportion. The photoactive materials were spin-coated with a rotation speed of $800 \mathrm{rpm}$ in a glove box, and the resulting film was about $300 \mathrm{~nm}$ thick. The P3HT:PCBM blend film was then annealed at $120^{\circ} \mathrm{C}$ for $10 \mathrm{~min}$ to reduce contact resistance of electrodes. Finally, a $120 \mathrm{~nm}$ thick $\mathrm{Ca} / \mathrm{Al}$ electrode was deposited onto the P3HT:PCBM blend film through a shadow mask by thermal evaporation. The current density

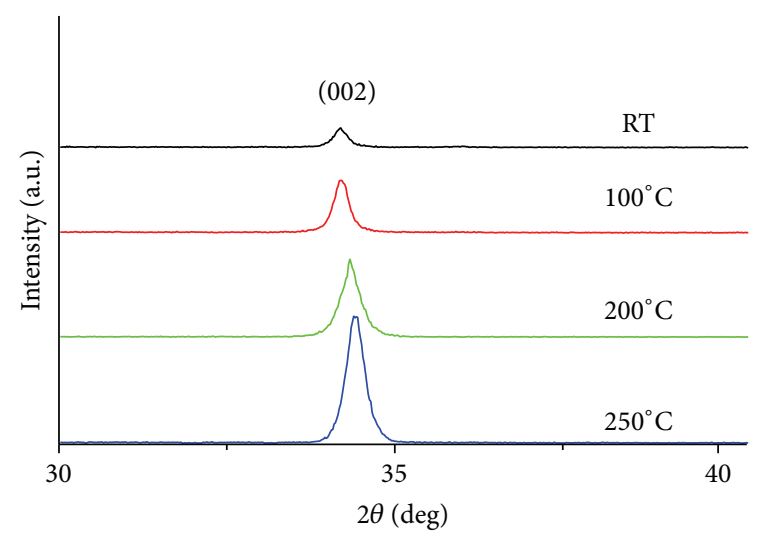

FIgure 1: The (002) X-ray diffraction spectra of the GAZO films deposited at RT, $100^{\circ} \mathrm{C}, 200^{\circ} \mathrm{C}$, and $250^{\circ} \mathrm{C}$.

TABLE 1: The measured atomic percent of zinc, oxygen, gallium, and aluminum for the GAZO films deposited at RT, $100^{\circ} \mathrm{C}, 200^{\circ} \mathrm{C}$, and $250^{\circ} \mathrm{C}$.

\begin{tabular}{lcccc}
\hline $\begin{array}{l}\text { Substrate } \\
\text { temperature }\left({ }^{\circ} \mathrm{C}\right)\end{array}$ & $\mathrm{Zn}(\mathrm{at} \%)$ & $\mathrm{O}(\mathrm{at} \%)$ & $\mathrm{Ga}(\mathrm{at} \%)$ & $\mathrm{Al}(\mathrm{at} \%)$ \\
\hline $\mathrm{RT}$ & 45.16 & 51.92 & 1.29 & 1.62 \\
100 & 45.31 & 49.55 & 1.81 & 1.53 \\
200 & 44.49 & 52.54 & 1.83 & 1.14 \\
250 & 43.38 & 53.32 & 2.21 & 1.09 \\
\hline
\end{tabular}

voltage measurements were obtained by using a source meter (Keithley, 2410) and a solar simulator (TELTEC) with an AM 1.5 illumination and intensity of $100 \mathrm{~mW} / \mathrm{cm}^{2}$.

\section{Results and Discussion}

3.1. Structural Properties. All the GAZO films deposited at various temperatures have only (002) preferential direction obtained from the spectra of X-ray diffraction (XRD). The (002) peak in XRD spectra of the GAZO films deposited at $\mathrm{RT}, 100^{\circ} \mathrm{C}, 200^{\circ} \mathrm{C}$, and $250^{\circ} \mathrm{C}$ is shown in Figure 1 . The intensity of (002) peak increases, while the corresponding full width at half maximum decreases with deposition temperature. It indicates that the crystallinity of GAZO films improves with thermal energy provided by heating substrate during sputtering. The (002) peak shifts to a higher angle with rising deposition temperature, which means that the adjacent (002) interplanar distance of GAZO films decreases with deposition temperature of GAZO films. This phenomenon could be related to more $\mathrm{Ga}$ and $\mathrm{Al}$ atoms substitution for $\mathrm{Zn}$ in $\mathrm{ZnO}$ crystal lattice when GAZO films were deposited at high temperatures, since the ionic and covalent radii of $\mathrm{Ga}$ and $\mathrm{Al}$ are smaller than those of $\mathrm{Zn}$ [11].

The atomic percent in films composition of the GAZO films deposited at RT, $100^{\circ} \mathrm{C}, 200^{\circ} \mathrm{C}$, and $250^{\circ} \mathrm{C}$ is listed in Table 1. The impurities, both $\mathrm{Ga}$ and $\mathrm{Al}$, were found for all GAZO films deposited at different temperatures. The atomic percent of $\mathrm{Al}$ decreases while that of $\mathrm{Ga}$ increases with deposition temperature. The $\mathrm{Al}$ in $\mathrm{AZO}$ films is thermally 


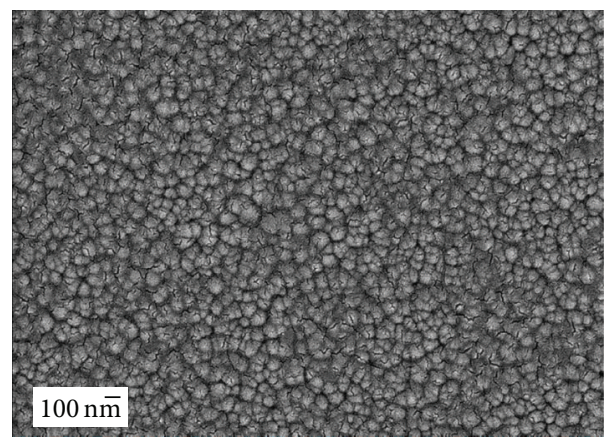

(a)

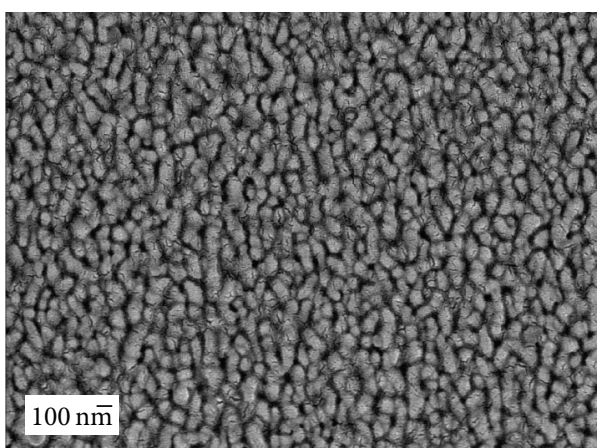

(c)

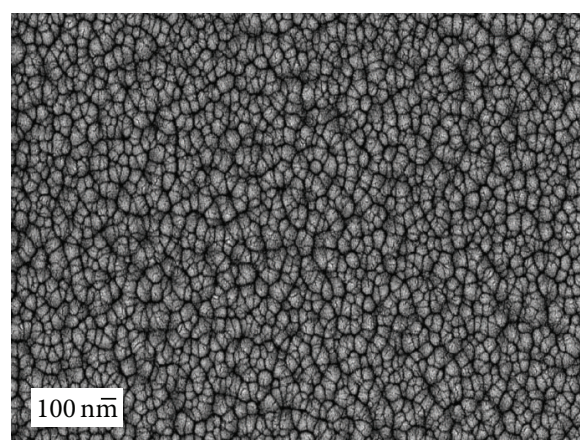

(b)

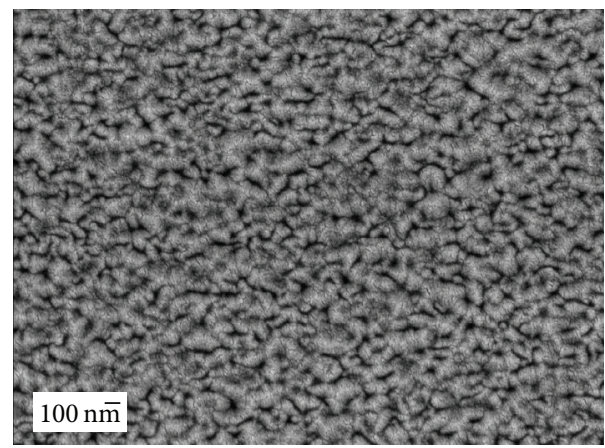

(d)

Figure 2: SEM micrographs of the GAZO films deposited at (a) RT, (b) $100^{\circ} \mathrm{C}$, (c) $200^{\circ} \mathrm{C}$, and (d) $250^{\circ} \mathrm{C}$.

TABLE 2: Comparison of reported GAZO films on deposition method and electrical and optical properties.

\begin{tabular}{|c|c|c|c|c|c|c|c|}
\hline Number & Year & Author(s) & Deposition method & Target(s) & $\begin{array}{l}\text { Lowest resistivity } \\
\qquad\left(10^{-4} \Omega-\mathrm{cm}\right)\end{array}$ & $\begin{array}{c}\text { Highest average optical } \\
\text { transmittance in visible } \\
\text { region }(\%)\end{array}$ & References \\
\hline 1 & 2009 & Shin et al. & Pulsed laser deposition & GAZO & 2.18 & 85 & {$[13]$} \\
\hline 2 & 2010 & Kang et al. & cosputtering & $\mathrm{GZO}+\mathrm{AZO}$ & 21.4 & 90 & {$[10]$} \\
\hline 3 & 2012 & Lin et al. & cosputtering & $\mathrm{GZO}+\mathrm{Al}$ sheet & 8.14 & $>80$ & {$[14]$} \\
\hline 4 & 2013 & Kim et al. & Facing targets sputtering & $\mathrm{GZO}+\mathrm{AZO}$ & 11.86 & 90 & {$[15]$} \\
\hline 5 & 2014 & Hong et al. & Facing targets sputtering & $\mathrm{GZO}+\mathrm{AZO}$ & 8.9 & 85 & {$[2]$} \\
\hline 6 & 2014 & Chang (this work) & In-line sputtering & GAZO & 4.3 & 92 & - \\
\hline
\end{tabular}

unstable which is found from our previous work [24]. The intensity of thermal desorption for $\mathrm{Al}$ is highest among $\mathrm{Zn}, \mathrm{O}$, and $\mathrm{Al}$ in $\mathrm{AZO}$ films. The $\mathrm{Al}$ in GAZO films may be thermally desorbed easier than other elements during films formation at high deposition temperature. This explains why the atomic percent of $\mathrm{Al}$ in GAZO films decreases with deposition temperature. Figures 2(a), 2(b), 2(c), and 2(d) show SEM micrographs of the GAZO films deposited at RT, $100^{\circ} \mathrm{C}$, $200^{\circ} \mathrm{C}$, and $250^{\circ} \mathrm{C}$. Grains of the GAZO films grow with deposition temperature observed from Figures 2(a) to 2(d). Coalescence between grains for GAZO films deposited at $250^{\circ} \mathrm{C}$ can be seen from Figure $2(\mathrm{~d})$. The phenomena of grain growth and coalescence can result from solid reaction induced by thermal energy during sputtering.

3.2. Electrical Properties. The electrical properties, carrier concentration, mobility, and electrical resistivity of the
GAZO films deposited at RT, $100^{\circ} \mathrm{C}, 200^{\circ} \mathrm{C}$, and $250^{\circ} \mathrm{C}$, are shown in Figures 3(a) and 3(b). The carrier concentration and mobility increase, while the electrical resistivity decreases with deposition temperature observed from Figures 3(a) and 3 (b). The electrical resistivity of the GAZO films decreases from $1.5 \times 10^{-3} \Omega \mathrm{cm}$ when films were deposited at RT and then decreases to $4.3 \times 10^{-4} \Omega \mathrm{cm}$ when deposited at $250^{\circ} \mathrm{C}$. Thermal energy supplied by heating substrate during sputtering results in more substitution from $\mathrm{Zn}$ to $\mathrm{Al}$ or $\mathrm{Ga}$ atoms in $\mathrm{ZnO}$ crystal lattice so as to increase the carrier concentration. Comparison of the lowest electric resistivity for GAZO films reported recently was shown in Table 2 . The lowest electric resistivity reported in this work demonstrates the lowest one for GAZO films deposited by sputtering listed in Table 2. In addition, this work uses one target with GAZO in composition instead of two targets of GZO and AZO to produce GAZO films. Comparing deposition methods in 


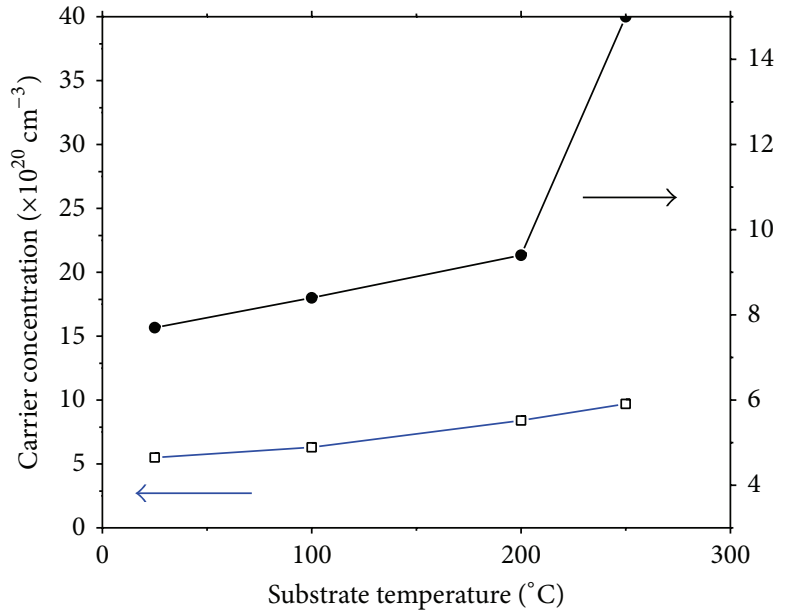

(a)

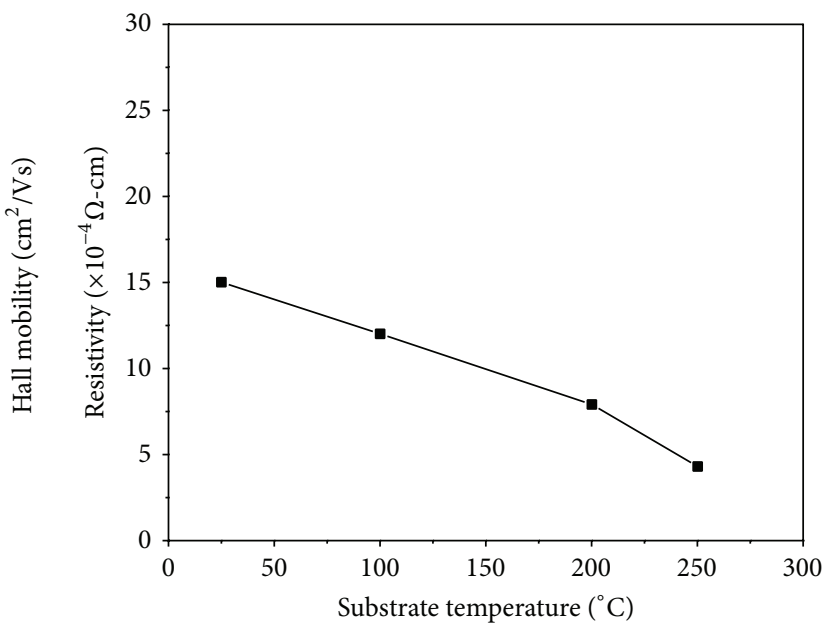

(b)

FIgUre 3: The (a) carrier concentration, mobility, and (b) electrical resistivity of the GAZO films deposited at RT, $100^{\circ} \mathrm{C}, 200^{\circ} \mathrm{C}$, and $250^{\circ} \mathrm{C}$.

Table 2, in-line sputtering used in this work is simple, with high throughput, and ready for large-area deposition.

3.3. Optical Properties. Figure 4 presents the optical transmittance spectra of the GAZO films deposited at RT, $100^{\circ} \mathrm{C}$, $200^{\circ} \mathrm{C}$, and $250^{\circ} \mathrm{C}$. Blue shift of the optical transmittance spectra with rising deposition temperature is clearly observed in inset of Figure 4, which can be attributed to Burstein-Moss effect $[25,26]$. The increase of the carrier concentration of the GAZO films with deposition temperature is mentioned in Section 3.2. The increase of carrier concentration widens the optical band gap of GAZO films. The average optical transmittance in the visible range from 400 to $800 \mathrm{~nm}$ of the GAZO films deposited at RT, $100^{\circ} \mathrm{C}, 200^{\circ} \mathrm{C}$, and $250^{\circ} \mathrm{C}$ was calculated and listed in Table 3 . The average optical transmittance of the GAZO films increases with deposition temperature. The average optical transmittance of the GAZO films increases from $75 \%$ to $92 \%$ when the deposition temperature of films was increased from RT to $250^{\circ} \mathrm{C}$. This phenomenon is caused by the reduction of materials defects at high deposition temperature. The thermal energy was provided by heating substrate during sputtering. The grains of GAZO films grow and crystallinity of GAZO films improves with deposition temperature observed from the results of SEM and XRD mentioned in Section 3.1, suggesting the number of materials defects in GAZO films decreases with deposition temperature. The average optical transmittance of GAZO films is therefore increased due to the reduction of materials defects in GAZO films. Comparison of the highest average optical transmittance in visible wavelength region for GAZO films reported recently was also collected in Table 2. The highest average optical transmittance in the visible region reported in this work demonstrates the highest one in Table 2.

3.4. Device Fabrication of Organic Solar Cells. The GAZO films deposited at $250^{\circ} \mathrm{C}$ possess good electrical and optical properties: the electrical resistivity of $4.3 \times 10^{-4} \Omega \mathrm{cm}$ and the

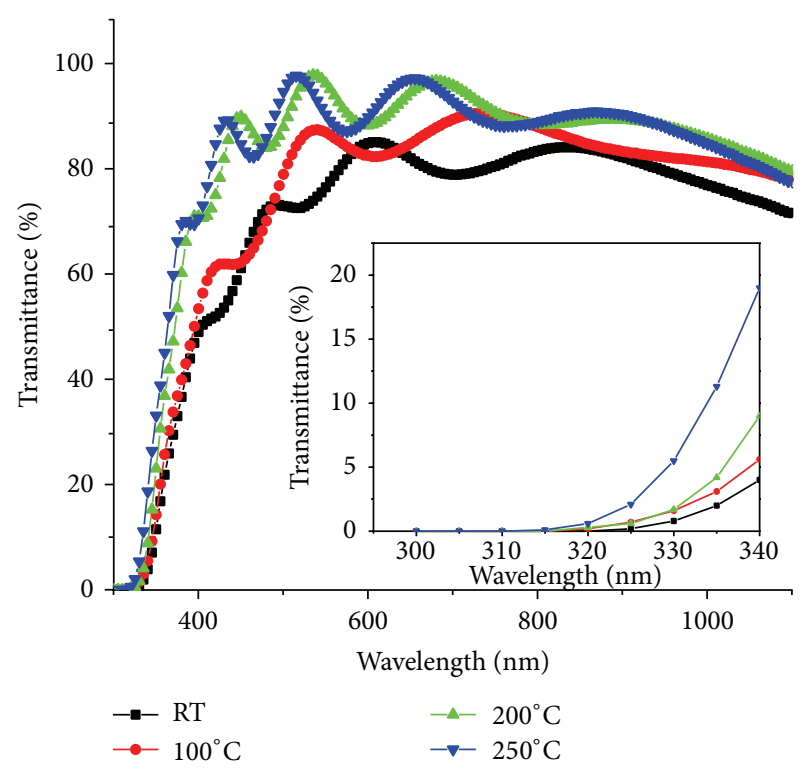

FIgURE 4: The optical transmittance spectra of the GAZO films deposited at $\mathrm{RT}, 100^{\circ} \mathrm{C}, 200^{\circ} \mathrm{C}$, and $250^{\circ} \mathrm{C}$.

TABLE 3: The average optical transmittance in visible range from 400 to $800 \mathrm{~nm}$ of the GAZO films deposited at RT, $100^{\circ} \mathrm{C}, 200^{\circ} \mathrm{C}$, and $250^{\circ} \mathrm{C}$.

\begin{tabular}{lc}
\hline $\begin{array}{l}\text { Substrate } \\
\text { temperature }\left({ }^{\circ} \mathrm{C}\right)\end{array}$ & $\begin{array}{c}\text { Average optical transmittance in } \\
\text { visible region from } 400 \text { to } 800 \mathrm{~nm}(\%)\end{array}$ \\
\hline RT & 75 \\
100 & 79 \\
200 & 91 \\
250 & 92 \\
\hline
\end{tabular}

average optical transmittance in visible region of $92 \%$. The hybrid OSC were fabricated on GAZO-coated glass substrates 


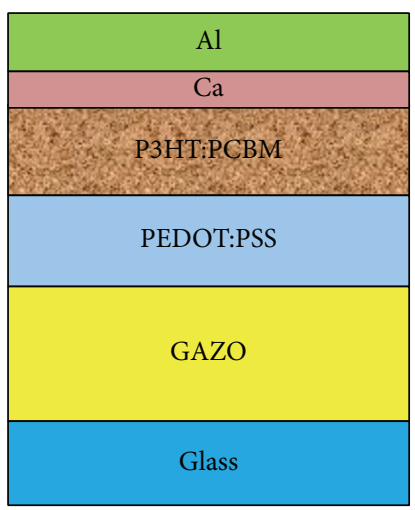

Figure 5: Device structure of fabricated OSC with the $250^{\circ} \mathrm{C}$ deposited GAZO electrode.

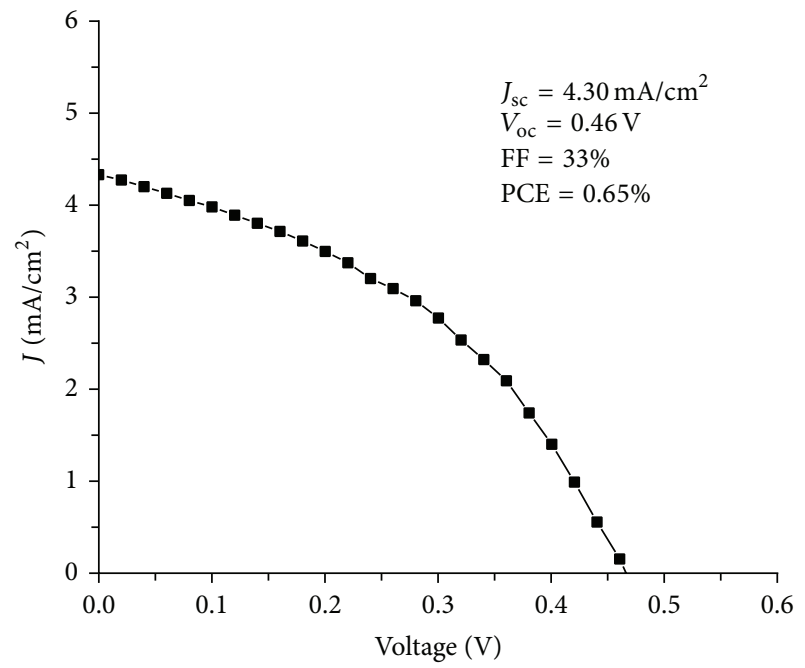

FIGURE 6: Current density versus voltage characteristics of fabricated OSC with the $250^{\circ} \mathrm{C}$ deposited GAZO electrode. $V_{\mathrm{oc}}, J_{\mathrm{sc}}, \mathrm{FF}$, and PCE in the inset of figure are open-circuit voltage, short-circuit current density, fill factor, and power conversion efficiency, respectively.

on which the GAZO films were deposited at $250^{\circ} \mathrm{C}$. The device structure of the produced OSC is shown in Figure 5. Calcium was inserted to improve the fill factor and the opencircuit voltage [27]. The organic layer of anhydrous molecular residues must be cared for because calcium oxidizes if it is exposed to oxygen and moisture [28]. The current densityvoltage characteristics of the fabricated OSC with the $250^{\circ} \mathrm{C}$ deposited GAZO electrode were measured under an illumination intensity of $100 \mathrm{~W} / \mathrm{cm}^{2}$ as shown in Figure 6. The power conversion efficiency of the fabricated OSC with the GAZO electrode is $0.65 \%$. The power conversion efficiency of OSC with the $250^{\circ} \mathrm{C}$ deposited GAZO electrode may improve with inverse structure in OSC where GAZO was used as the electron-collecting cathode [16, 20, 21].

\section{Conclusions}

The GAZO films were deposited by in-line sputtering. Structural, electrical, and optical properties of the GAZO films deposited at RT, $100^{\circ} \mathrm{C}, 200^{\circ} \mathrm{C}$, and $250^{\circ} \mathrm{C}$ were investigated. The deposition temperature shows positive influence on crystallinity and electrical and optical properties. The electric resistivity and average optical transmittance in the visible range from 400 to $800 \mathrm{~nm}$ are $1.3 \times 10^{-3} \Omega \mathrm{cm}$ and $75 \%$, respectively, for the GAZO films deposited at RT. They can improve to $4.3 \times 10^{-4} \Omega \mathrm{cm}$ and $92 \%$, respectively, for the GAZO films deposited at $250^{\circ} \mathrm{C}$. In-line sputtering presents a simple, mass-production, and large-area deposition method to produce both good electrical and optical properties of GAZO films reported recently. The P3HT:PCBM based OSC with the $250^{\circ} \mathrm{C}$ deposited GAZO electrode were fabricated. The power conversion efficiency of the produced OSC is $0.65 \%$.

\section{Conflict of Interests}

The author declares that there is no conflict of interests regarding the publication of this paper.

\section{Acknowledgments}

The author would like to thank the National Science Council of Taiwan for partial financial support (NSC 102-2221-E-168037-), Bay $\mathrm{Zu}$ Precision Corporation for providing in-line sputtering tool, and Kuang-Jung Wu for carrying out part of measurements.

\section{References}

[1] T. Minami and T. Miyata, "Present status and future prospects for development of non- or reduced-indium transparent conducting oxide thin films," Thin Solid Films, vol. 517, no. 4, pp. 1474-1477, 2008

[2] J. S. Hong, N. Matsushita, and K. H. Kim, "Investigation of the effect of oxygen gas on properties of GAZO thin films fabricated by facing targets sputtering system," Semiconductor Science and Technology, vol. 29, no. 7, Article ID 075007, 2014.

[3] J. X. Jiang, F. L. Wong, M. K. Fung, and S. T. Lee, "Aluminumdoped zinc oxide films as transparent conductive electrode for organic light-emitting devices," Applied Physics Letters, vol. 83, no. 9, pp. 1875-1877, 2003.

[4] L. Raniero, I. Ferreira, A. Pimentel et al., "Role of hydrogen plasma on electrical and optical properties of ZGO, ITO and IZO transparent and conductive coatings," Thin Solid Films, vol. 511-512, pp. 295-298, 2006.

[5] S. Mridha and D. Basak, "Aluminium doped $\mathrm{ZnO}$ films: electrical, optical and photoresponse studies," Journal of Physics D: Applied Physics, vol. 40, no. 22, pp. 6902-6907, 2007.

[6] J. Lee, D. Lee, D. Lim, and K. Yang, "Structural, electrical and optical properties of $\mathrm{ZnO}$ :Al films deposited on flexible organic substrates for solar cell applications," Thin Solid Films, vol. 515, no. 15, pp. 6094-6098, 2007.

[7] B. Z. Dong, G. J. Fang, J. F. Wang, W. J. Guan, and X. Z. Zhao, "Effect of thickness on structural, electrical, and optical properties of $\mathrm{ZnO}$ : Al films deposited by pulsed laser deposition," Journal of Applied Physics, vol. 101, no. 3, Article ID 033713, 2007.

[8] H. J. Ko, Y. F. Chen, S. K. Hong, H. Wenisch, T. Yao, and D. C. Look, "Ga-doped $\mathrm{ZnO}$ films grown on $\mathrm{GaN}$ templates by 
plasma-assisted molecular-beam epitaxy," Applied Physics Letters, vol. 77, no. 23, pp. 3761-3763, 2000.

[9] V. Assunção, E. Fortunato, A. Marques et al., "Influence of the deposition pressure on the properties of transparent and conductive $\mathrm{ZnO}: \mathrm{Ga}$ thin-film produced by r.f. sputtering at room temperature," Thin Solid Films, vol. 427, no. 1-2, pp. 401-405, 2003.

[10] J. Kang, H. W. Kim, and C. Lee, "Electrical resistivity and transmittance properties of Al- and Ga-codoped $\mathrm{ZnO}$ thin films," Journal of the Korean Physical Society, vol. 56, no. 2, pp. 576579, 2010.

[11] W. B. Pearson, Crystal Chemistry and Physics of Metals and Alloys, Wiley, New York, NY, USA, 1972.

[12] Q.-B. Ma, Z.-Z. Ye, H.-P. He, L.-P. Zhu, J.-R. Wang, and B.-H. Zhao, "Influence of $\mathrm{Ar} / \mathrm{O} 2$ ratio on the properties of transparent conductive $\mathrm{ZnO}: \mathrm{Ga}$ films prepared by DC reactive magnetron sputtering," Materials Letters, vol. 61, no. 11-12, pp. 2460-2463, 2007.

[13] J.-H. Shin, D.-K. Shin, H. Y. Lee, and J.-Y. Lee, "Characteristics of gallium and aluminum Co-doped $\mathrm{ZnO}$ (GAZO) transparent thin films deposited by using the PLD process," Journal of the Korean Physical Society, vol. 55, no. 3, pp. 947-951, 2009.

[14] Y. C. Lin, T. Y. Chen, L. C. Wang, and S. Y. Lien, "Comparison of AZO, GZO, and AGZO thin films TCOs applied for a-Si solar cells," Journal of the Electrochemical Society, vol. 159, no. 6, pp. H599-H604, 2012.

[15] K. H. Kim, H. W. Choi, and K. H. Kim, "Effect of working pressure on the characteristics of $\mathrm{Ga}-\mathrm{Al}$ doped $\mathrm{ZnO}$ thin films deposited by the facing targets sputtering method," Journal of Ceramic Processing Research, vol. 14, no. 2, pp. 194-197, 2013.

[16] J. Owen, M. S. Son, K. H. Yoo, B. D. Ahn, and S. Y. Lee, "Organic photovoltaic devices with Ga-doped $\mathrm{ZnO}$ electrode," Applied Physics Letters, vol. 90, no. 3, Article ID 033512, 2007.

[17] S. Park, S. J. Tark, J. S. Lee, H. Lim, and D. Kim, "Effects of intrinsic ZnO buffer layer based on P3HT/PCBM organic solar cells with Al-doped ZnO electrode," Solar Energy Materials and Solar Cells, vol. 93, no. 6-7, pp. 1020-1023, 2009.

[18] T. L. Chen, R. Betancur, D. S. Ghosh, J. Martorell, and V. Pruneri, "Efficient polymer solar cell employing an oxidized $\mathrm{Ni}$ capped $\mathrm{Al}: \mathrm{ZnO}$ anode without the need of additional holetransporting-layer," Applied Physics Letters, vol. 100, no. 1, Article ID 013310, 2012.

[19] H. Liu, Z. Wu, J. Hu et al., "Efficient and ultraviolet durable inverted organic solar cells based on an aluminum-doped zinc oxide transparent cathode," Applied Physics Letters, vol. 103, no. 4, Article ID 043309, 2013.

[20] D. Chen, C. Zhang, Z. Wang et al., "Efficient indium-tin-oxide free inverted organic solar cells based on aluminum-doped zinc oxide cathode and low-temperature aqueous solution processed zinc oxide electron extraction layer," Applied Physics Letters, vol. 104, Article ID 243301, 2014.

[21] T. Shi, X. Zhu, and G. Tu, "Efficient inverted polymer solar cells based on ultrathin aluminum interlayer modified aluminumdoped zinc oxide electrode," Applied Physics Letters, vol. 104, Article ID 103901, 2014.

[22] S.-C. Chang, Y.-J. Hsiao, and T.-S. Li, "P3HT:PCBM incorporated with silicon nanoparticles as photoactive layer in efficient organic photovoltaic devices," Journal of Nanomaterials, vol. 2013, Article ID 354035, 4 pages, 2013.

[23] S.-C. Chang, Y.-J. Hsiao, and T.-S. Li, "Improving the power conversion efficiency of organic solar cell by blending with
CdSe/ZnS core-shell quantum dots," Journal of Electronic Materials, 2014.

[24] S.-C. Chang, T.-C. Lin, and T.-S. Li, “Thermal effect on the structural, electrical, and optical properties of in-line sputtered aluminum doped zinc oxide films explored with thermal desorption spectroscopy," Journal of Nanomaterials, vol. 2014, Article ID 690498, 6 pages, 2014.

[25] E. Burstein, "Anomalous optical absorption limit in InSb," Physical Review, vol. 93, no. 3, pp. 632-633, 1954.

[26] T. S. Moss, "The interpretation of the properties of indium antimonide," Proceedings of the Physical Society B, vol. 67, no. 10, article 306, pp. 775-782, 1954.

[27] Q. Liu, Z. Liu, X. Zhang et al., "Polymer photovoltaic cells based on solytion-processable graphene and P3HT," Advanced Functional Materials, vol. 19, no. 6, pp. 894-904, 2009.

[28] B. Paci, A. Generosi, V. R. Albertini, P. Perfetti, R. de Bettignies, and C. Sentein, "Time-resolved morphological study of organic thin film solar cells based on calcium/aluminium cathode material," Chemical Physics Letters, vol. 461, no. 1-3, pp. 77-81, 2008. 

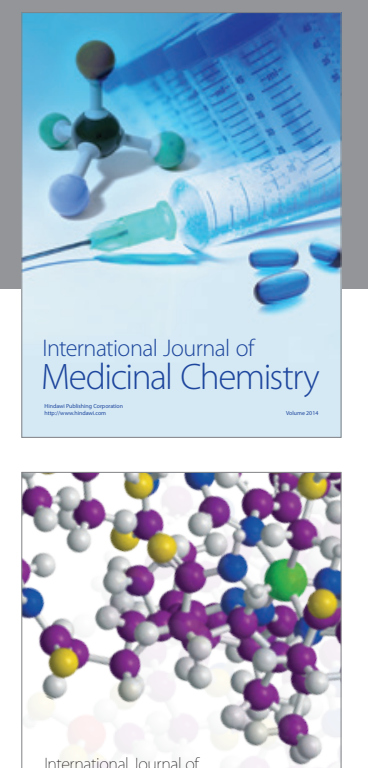

\section{Carbohydrate} Chemistry

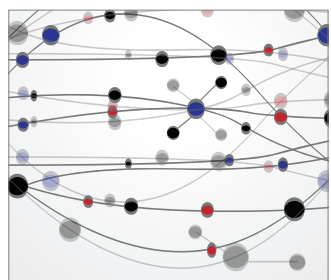

The Scientific World Journal
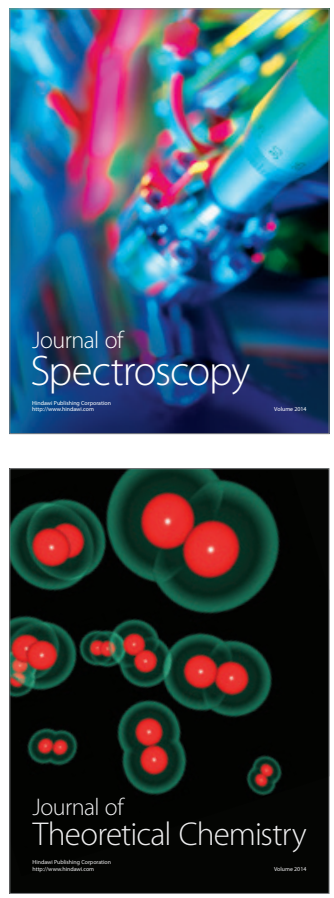
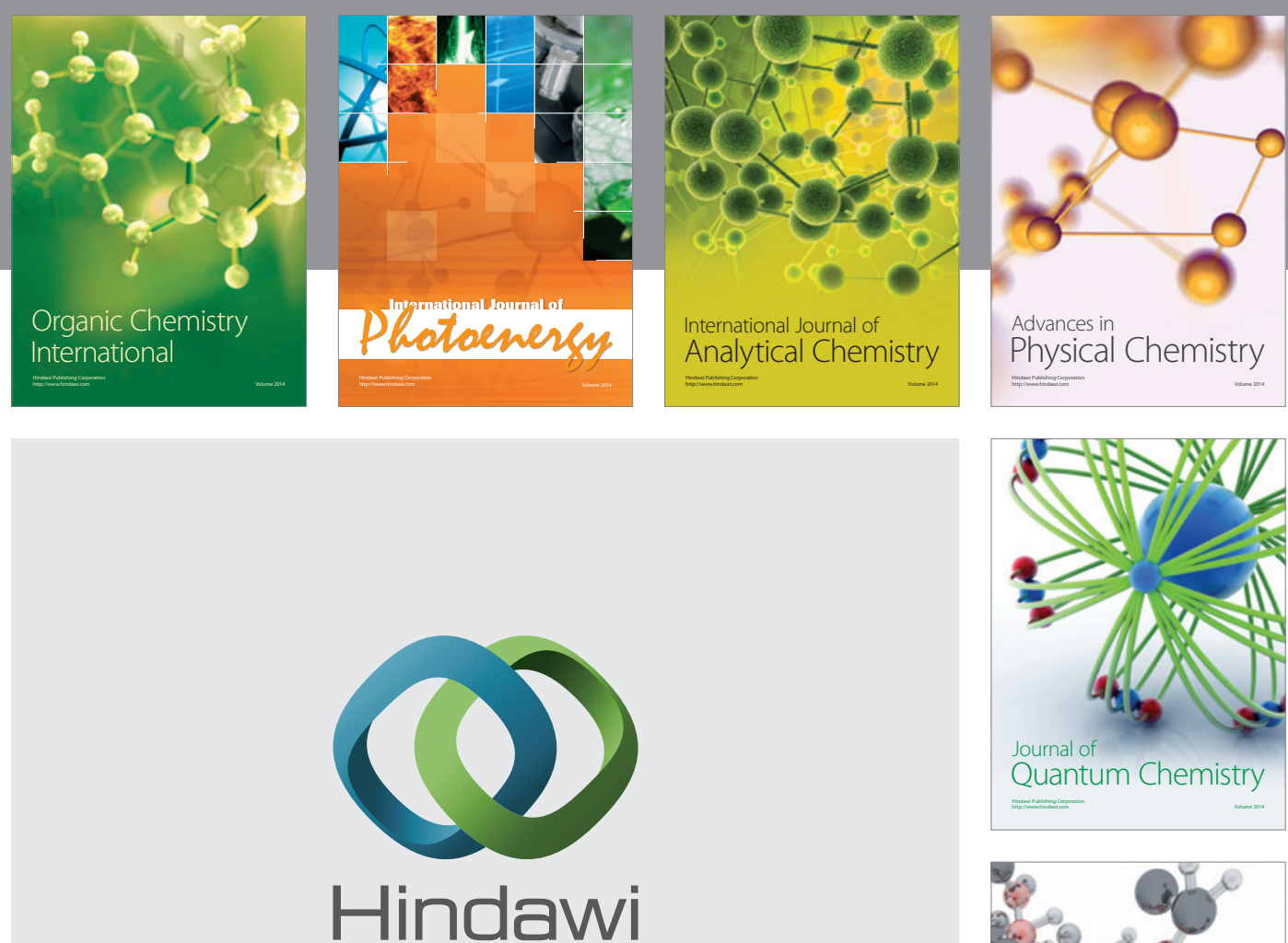

Submit your manuscripts at

http://www.hindawi.com

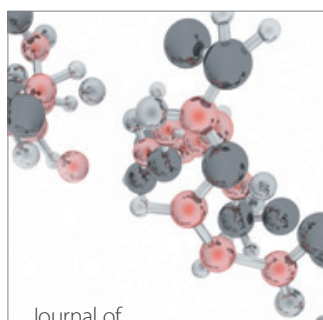

Analytical Methods

in Chemistry

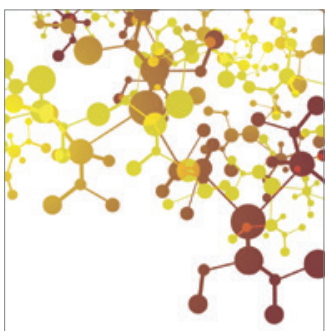

Journal of

Applied Chemistry

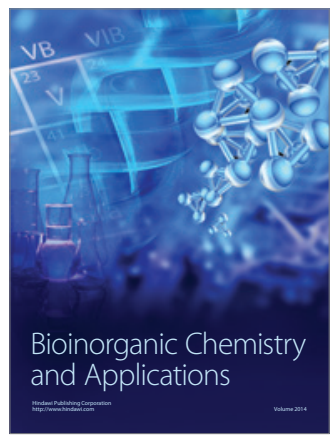

Inorganic Chemistry
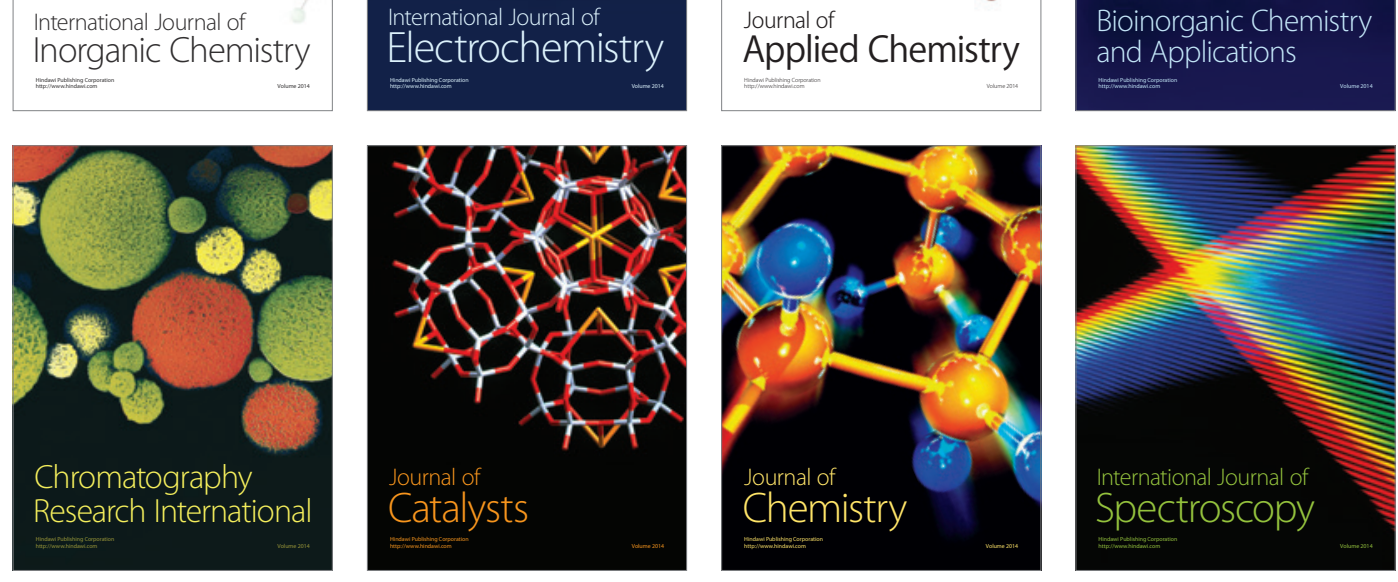